\author{
G.K. Shambilova ${ }^{1}$, I.V. Gumennyi ${ }^{2}$, V.A. Govorov ${ }^{2}$, \\ A.Ya. Malkin ${ }^{2}$, V.E. Makhatova ${ }^{1}$, M.Zh. Naukenov ${ }^{3}$ \\ ${ }^{I}$ Kh. Dosmukhamedov Atyrau State University, Kazakhstan; \\ ${ }^{2}$ A.V. Topchiev Institute of Petrochemical Synthesis, Russian Academy of Sciences, Moscow, Russia; \\ ${ }^{3}$ "Atyrau oil refinery» LLP, Kazakhstan \\ (E-mail: shambilova_gulba@mail.ru)
}

\title{
Polysulfone as a material for advanced electrical batteries
}

\begin{abstract}
The materials based on polysyphone are used for polymer electrolite production. The rheological properties were measured for three component system polysulphone - solvent - propylene carbonate. The varying factor was propylene carbonate used as a plasticizer for polysulphone. Experiments were carried out in a wide shear rate and frequency ranges at $25^{\circ} \mathrm{C}$. Polymer was characterized by the IR-spectral method. Rheological experiments were carried out using the technique of rotational rheometry. It was shown that the rheological behavior of all samples is linear and these three-component systems are viscoelastic liquids. It can be assumed that all systems under study at homogeneous in the absence of traces of water. The final goal of the study was the choice of the optimal composition (concentrations of a solvent and plasticizer) and the regime of preparing thin films from these systems which could provide obtaining solid state electrolyte for creating advanced electrical accumulator with a none-fragile polysulfone membrane. This part of the research is devoted to investigation of the rheological properties (viscosity and viscoelastic properties of composition of polysulfone solvent - propylene carbonate systems.
\end{abstract}

Keywords: polysulfone, polymer solutions, plasticizer, viscosity, viscoelastic properties, solid-state electrolyte, thin-film membrane.

\section{Introduction}

Secondary sources of electrical energy are widely spread and used in the modern world. Nowadays, the basic element of such a kind is a lithium-ionic accumulator which is almost exclusively used in portable electronics as well as it is a perspective power supply for electric transport. Advantages of lithium-ionic accumulator are high store energy density, absence of a memory effect, and long term exploitation [1, 2]. Meanwhile, their essential defect is using liquid electrolytes. Thus does not allow for decreasing size of a power source to a film of several microns, impossibility to create flexible battery and provide necessary safety. Therefore, today we meet an increasing number of publications and research aimed to using a solid electrolyte/separator [3, 4].

The general way for building thin-film battery is creating a polymeric matrix which is acting of electrolyte and separator and this construction determines the mechanical properties of a battery in whole providing the formation of a stable 3D structure [5].

One of the most perspective polymers which can be used for these purposes is polysulfone. This term is common for the entire class of sulfo-group contacting compounds. A polymeric chain of these polymers contains para-aromatic groups bonded by esters and sulfonic group [6]. As a rule polysulfone is a rigid-chain amorphous polymer with relatively low molecular weight [7]. This is an engineering plastic with high mechanical performance in different modes of deformations (bending, extension, torsion) and high temperature stability (till $150-170 \pm{ }^{\circ} \mathrm{C}$ ). For this polymer, high chemical stability (in the $\mathrm{pH}$ range from 1 to 13 ), good resistance to oxidation [8]. In the same time this polymer can be dissolved in many aprotonic solvents such as dimethylacetamide and methylpyrrolidone. However there are serious difficulties in preparing polysulfone films because they appear brittle and do not resist to deformations perpendicular to the film plate.

All these reasoning were the cause for this study. It was proposed to plasticizer polysulfone by using propylene carbonate as a plasticizer. It was presumed that this liquid will occupy free volume in the polymer bulk when the solvent from the polysulfone solution will be completely deleted.

This part of the research work is devoted to investigation of the rheological properties (viscosity and viscoelastic properties of polysulfone - solvent - propylene carbonate systems. 


\section{Experimental}

Objects. A sample of granulated polysulfone sample (produced under working conditions using the facility of the Institute of Plastics (Moscow), PSF-150 grade according to the manufacturer's standard) was used. N-Methylpyrrolidone purchased from LLC Ruskhim was used as the solvent. Solvent contained $0.1 \%$ of water (determined by the Fischer method). Propylene carbonate was bought from Chemical Ltd. The mass part of water was less than $0.05 \%$ (determined by the Fischer method).

Methods. Chemical structure of the polymer was confirmed by the Fourier IR spectroscopy using the IFS-66 v/s instrument (Bruker, Germany) - scan-30, resolution of $2 \mathrm{sm}^{-1}$, range of $0-4000 \mathrm{sm}^{-1}$.

Three component solutions were obtained in two stages. At first stage, a plasticizer was added to a given quantity of a solvent. The mixture was placed into a ultrasonic bath for $10 \mathrm{~min}$. At the second stage, the polymer was introduced into the beforehand mixture and a sample stirred in a mechanical stirrer during 7 hours at a speed of 800 RPM under permanent heating at $100^{\circ} \mathrm{C}$. Samples with constant polymer - solvent ratio was used and the quantity of plasticizer varied from 10 to $60 \%$ in relation to the polymer mass.

Rheological properties of all highly concentrated systems were measured on a rotation rheometer Kinexus Pro (MalvernPananalytical). Temperature was regulated using the Peltier element with thermal stabilization of the measuring system with an active cover. The latter allowed us to prevent heat lose and minimize temperature gradients inside a sample.

The procedure of measuring has been carried out using the cone-and-plate and plate-and-plate working units. The angle between the cone and the plate was $1^{\circ}$; the cone diameter was $40 \mathrm{~mm}$. When the plate-andplate system was used, the diameter of the user plate was $20 \mathrm{~mm}$. All experimental data were obtained at $25^{\circ} \mathrm{C}$. The range of the given shear rate in measuring the apparent viscosity was from 0.01 to $100 \mathrm{~s}^{-1}$. The number of points in scanning was 10 .

In the amplitude test at measuring viscoelastic parameters of the samples, the amplitude of strain was varied from $0.01 \%$ to $30 \%$ at the frequency of $1 \mathrm{~Hz}$.

In measuring frequency dependencies of the components of the dynamic modulus, the frequency varied from 0.01 to $50 \mathrm{~Hz}$.

\section{Results and Discussion}

Figure 1 shows the IR spectrum of the used polysulfone sample. The aim of this test was to determine the exact molecular structure of the used polymer from great variety of possible polysulfones. As is seen, the obtained spectrum demonstrates the presence of $n$-substituted phenyl rings $\left(690-850 \mathrm{~cm}^{-1}\right.$ band) corresponding to non-plane stretching vibrations $\mathrm{C}=\mathrm{C}-\mathrm{H}$ group, vibrations of $\mathrm{C}=\mathrm{C}$ groups ( 1489 and $1585 \mathrm{~cm}^{-1}$ bands), and $\mathrm{C}-\mathrm{H}$ stretching vibrations (3060 $\mathrm{cm}^{-1}$ band). $1000-1050 \mathrm{~cm}^{-1}$ band corresponds to isopropylidene group, $1360-1420 \mathrm{~cm}^{-1}$ band to $\mathrm{C}-\mathrm{C}$ group, $2770-2840 \mathrm{~cm}^{-1}$ to methyl groups, bands in the range 1150 и $1330 \mathrm{~cm}^{-1}$ are responsible to sulfone groups $<$ bands of 1242 и $1103 \mathrm{~cm}^{-1}$ are related to $\mathrm{Ph}-\mathrm{O}-\mathrm{Ph}$ bonds and angles.

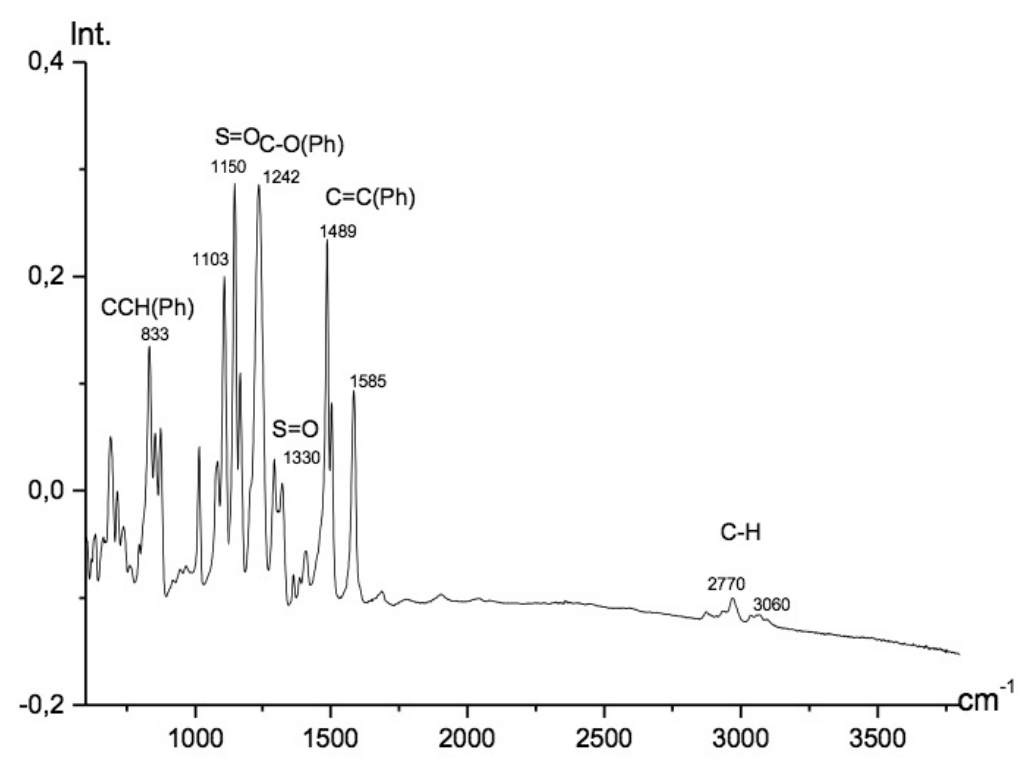

Figure 1. IR-spectrum of polysulfone sample used in the work 
So, the analysis of the IR-spectrum and comparison with the database shows that our sample is identical to $p$-phenylsulfone.

The main problem in preparing polysulfone thin films is inherently connected with the pre-history of their solvation. Therefore just the rheology of polymer solutions can give answers and prompt the optimal protocol for obtaining films with necessary characteristics because the structure of solid polymer in a film is created in a previous solution.

Figure 2 shows the dependencies of the apparent viscosity on shear rate for a series of plasticized solutions. The viscosity of the initial sample (without of a plasticizer) is $40 \mathrm{~Pa} \cdot \mathrm{s}$. This solution demonstrates the Newtonian type of the rheological behavior. The same remains true for all plasticizer solutions.

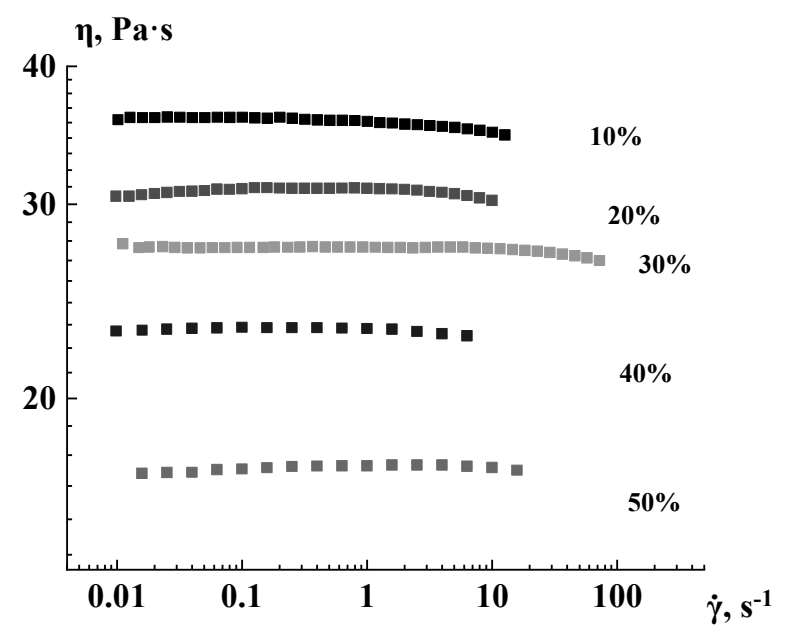

Figure 2. Dependencies of the apparent viscosity on shear rate for samples with different concentration of the plasticizer

So, there is a three - component system. This (Newtonian) character of the flow can be presumably, explained by a rather low concentration of the polymer in the composition. Indeed, the share of a plasticizer in the composition in whole varies from $3 \%$ to $15 \%$. It corresponds to an increase of the total content of low-molecular weights liquids from $67 \%$ to $71 \%$, i.e. it leads to dilution of a solvent. In this case, presumably, a system remains homogeneous and the decrease of the polymer concentration results to a decrease in the viscosity. Actually the viscosity of a system decreases as seen from Figure 2 . This is also clearly seen in Figure 3 where the dependence of the viscosity of tree-components solutions on the plasticizer concentration is presented.

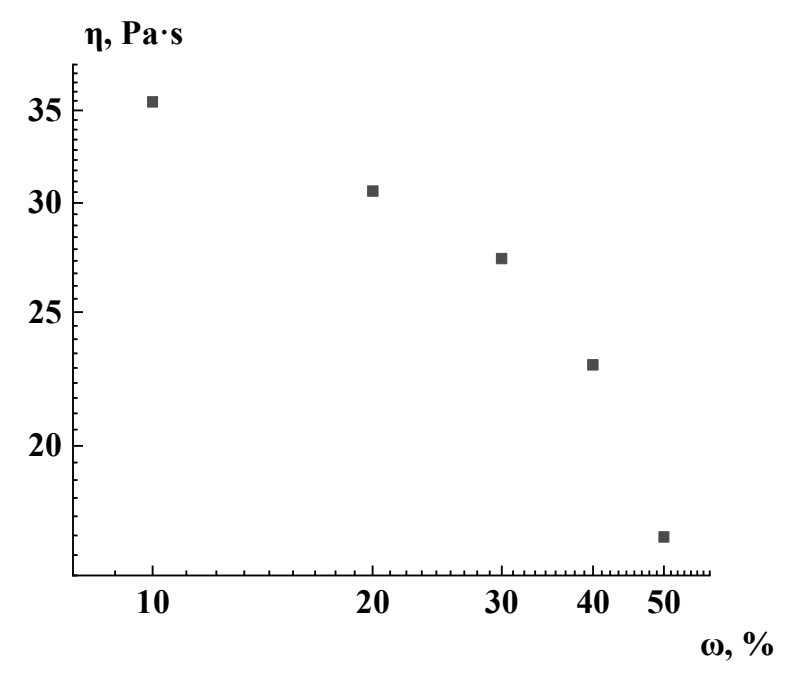

Figure 3. Dependence of the viscosity of three-components systems on the concentration of the plasticizer 
The results of measuring viscoelastic properties of the systems under study are presented in Figures 4 and 5.

Amplitude dependencies of the components of the complex elastic modulus are shown in Figure 4 for a single frequency of $1 \mathrm{~Hz}$. One can see that the viscoelastic response remains linear in a rather wide amplitude range. It confirmed that the structure of all these systems is rather stable. In particularly it means that the results of measuring frequency dependencies of the elastic modulus are really relate to the linear domain of the viscoelastic behavior of solutions. These results are shown in Figure 5.
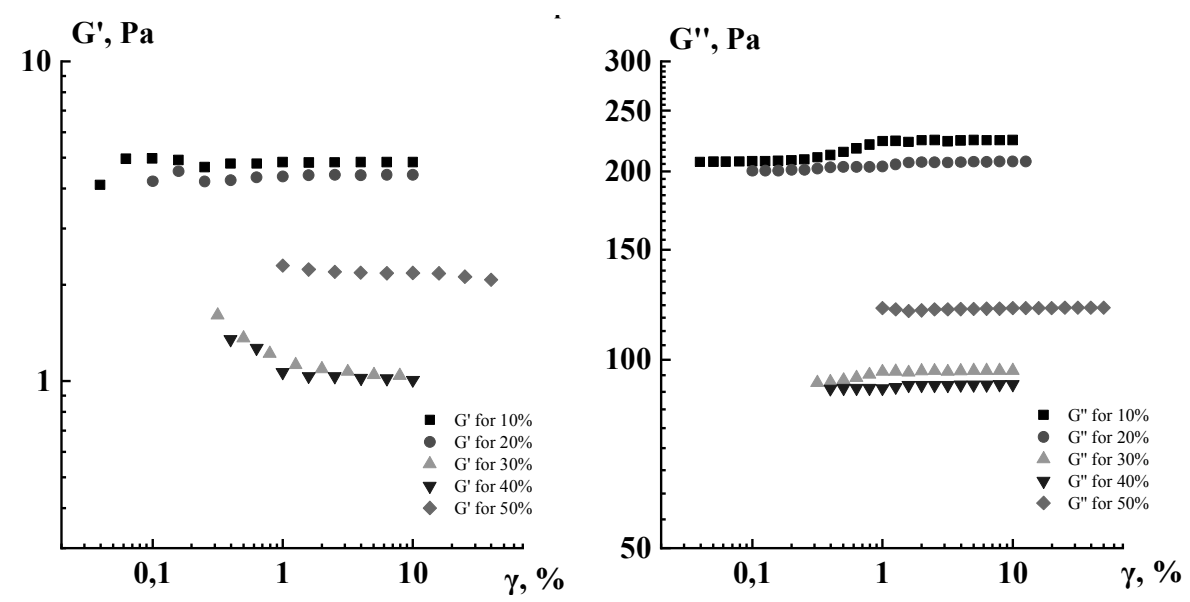

Figure 4. Amplitude test for the storage modulus $(a)$ and the loss modulus $(b)$ made mod different concentration of the plastisizer $(\mathrm{f}=1 \mathrm{~Hz})$
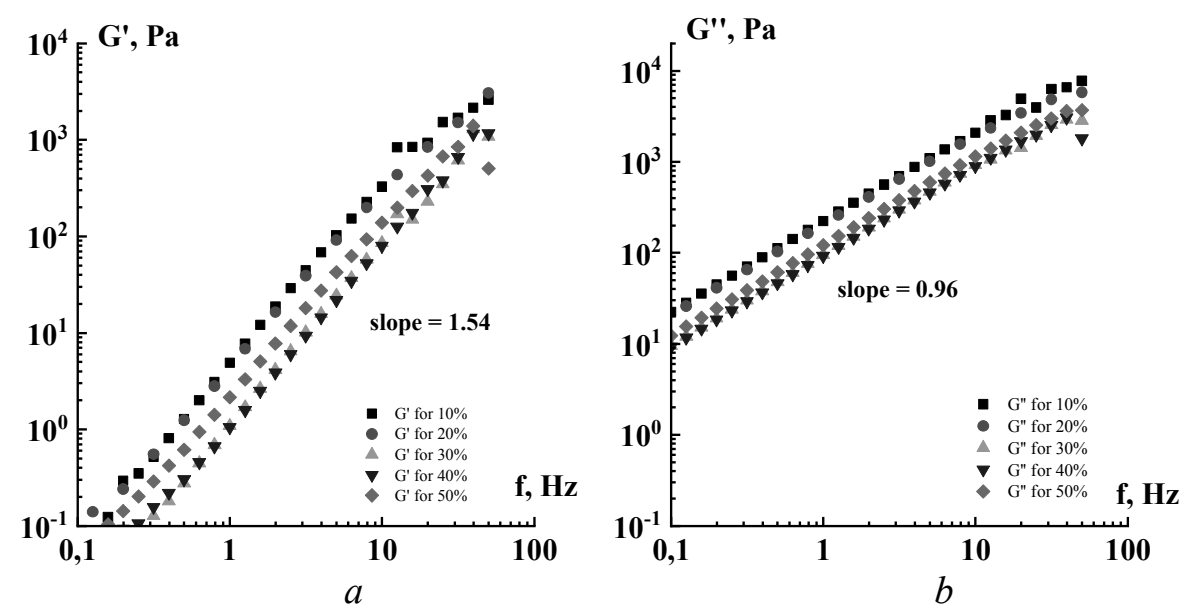

Figure 5. Frequency dependencies of the component of the dynamic modulus: the storage modulus $(a)$ and the loss modulus $(b)$ for systems with different concentration of the plasticizer

For all compositions, experimental data show that $G^{\prime \prime} \gg G^{\prime}$, i.e. liquid component dominates and all compositions are elastic fluids. The slope of the storage modulus is 1.54 that is much lower than the value corresponding to the Maxwell singly-relaxation-time model. So, it is necessary to assume that relaxation spectra of solutions are rather wide. This is related to the presence of polymeric chains with their inherent segmental movement because polysulfone macromolecules are rather semi-rigid than rigid.

Experimental curves are placed rather systematically with exclusion of the most concentrated $(50 \%)$ solution. It is reasonable to suspect that this is a limit of solubility of polysulfone. Similar results have been obtained for a two-component polysulfone solutions in our previous publication [9].

\section{Conclusion}

The results of the rheological study of complex tree-component solution (polysulfone, solvent, plasticizer) have been presented. These results include data on the apparent viscosity and viscoelastic properties in 
a wide concentration range. These data are important for the choice of the optimal composition and regime of preparing thin-film solid membrane and solid electrolyte for advanced electrical accumulators.

\title{
References
}

1 Linden, D., \& Thomas, B. Reddy (2001). Handbook of Batteries. New York: McGraw-Hill.

2 Clause, D., Besenhard, J. O. (2012). Handbook of Battery Materials. (2nd ed.). Germany: Weinheim.

3 Yoshinobu, T. (2015). Ion Exhange Membranes. (2nd ed.). Japan: IEM Research Ibaraki Prefecture.

4 Tarascon, J.-M., \& Armand, M. (2005). Issues and challenges facing rechargeable batteries. Nature Materials, 4, $366-377$.

5 Qingwen, L., \& Jianhua, F. (2013). A novel solid composite polymer electrolyte based on poly(ethylene oxide) segmented polysulfone copolymers for rechargeable lithium batteries. Journal of Membrane Science. China: Shanghai, 105-112.

6 Solvay Advanced Polymer UDEL polysulfone design guide (2018). Issue 2.1. www.solvay.com Retrieved from https://www.solvay.com/sites/g/files/srpend221/files/2018-08/Udel-PSU-Design-Guide_EN-v5.0_0_0.pdf.

7 David, P. (2005). ICI Advanced Materials. United Kingdom: Middleborough.

8 Anca, F., \& Albu, R.M. (2016). Blends based on ionic polysulfones with improved conformational and microstructural characteristics: Perceptive for biomedical applications. Romania: Lasi.

9 Shambilova, G.K., Pavlyuchkova, E.A., Govorov, V.A., Gumennyi, I.V., Taltenov, A.A., \& Malkin, A. Ya. (2019). Rheology of Polysulfone and Its Solutions. Polymer Science, Ser. A, 61, 2, 208-214.

\author{
Г.К. Шамбилова, И.В. Гуменный, В.А. Говоров, \\ А.Я. Малкин, В.Е. Махатова, М.Ж. Наукенов
}

\section{Заманауи электр аккумуляторлары үшін полисульфонды қолдану туралы}

\begin{abstract}
Полимерлі электролиттер мен сепараторды жасау үшін полисульфон негізіндегі материалдар қолданылды. Полисульфон негізіндегі үшкомпоненті жүйелер үшін реологиялық сипаттамалары (көрінуші тұтқырлықтың ығысу жылдамдығынан тәуелділігі, тұтқырсерпімді кешен модулінің амплитудалық және жиеліктік тәуелділігі) зерттелді. Бастапқы жүйе N-метилпирролидондағы полимердің ерітіндісі. Пластификатор ретінде пропиленкарбонат қолданылды, жұмыста ерітінділердің реологиялық қасиеттерінің пластификатор концентрациясына тәуелділігі зерттелді. Эксперименттер $25^{\circ} \mathrm{C}$ температурада, жылдамдықтар мен жылжу жиіліктерінің кең ауқымында жүргізілді. Бастапқы полимер ИҚ-спектроскопия әдісімен сипатталды. Реологиялық эксперименттер ротациялық реометрия техникасын пайдалану арқылы жүргізілді. Барлық зерттелген үлгілер үшін жылжу жылдамдығына тұтқырлықтың тәуелділігі ньютондық болып және мұндай үш компонентті жүйелер тұтқыр-шеңбер сұйықтықтар болып табылатыны көрсетілді. Зерттелген үлгілердің реологиялық сипаттамалары сызықтық және мұндай үш компонентті жүйелер тұтқырсерпімді сұйықтықтар болып табылатыны көрсетілді. Барлық зерттелетін жүйелерді су іздері болмаған кезде біртектес деп болжауға болады. Зерттеудің соңғы мақсаты оңтайлы құрамды материал (еріткіштің және пластификатордың концентрациясы) және осы жүйелерден жұқа пленкаларды дайындау режимін таңдау болды, олар электролит пен сепаратор рөлінде қолдануға жарамды, икемді полисульфон мембранамен жетілдірілген электр аккумуляторын жасау үшін қатты электролит алуды қамтамасыз ете алады. Бұл жұмыс полисульфон - еріткіш - пропиленкарбонат жүйелерінің тұтқырлығы мен тұтқырсерпімділігі сияқты реологиялық қасиеттерін және олардың ерітінділердің құрамы мен құрылымына тәуелділігін зерттеуге арналған.
\end{abstract}

Кілт сөздер: полисульфон, полимерлі ерітінділер, пластификатор, тұтқырлық, тұтқырсерпімділік қасиеттері, қатты электролит, жұқа пленкалы мембрана.

\author{
Г.К. Шамбилова, И.В. Гуменный, В.А. Говоров, \\ А.Я. Малкин, В.Е. Махатова, М.Ж. Наукенов
}

\section{Полисульфон как материал для современных электрических аккумуляторов} Материалы на основе полисульфона используются как основа для создания полимерных электролитов
и сепараторов. Реологические свойства (зависимость кажущейся вязкости от скорости сдвига, а также
амплитудные и частотные зависимости компонента модуля вязкоупругого комплекса) были измерены
для трехкомпонентных систем на основе полисульфона. Исходная система - это раствор полимера в
N-метилпирролидоне. В качестве пластификатора применен пропиленкарбонат, в работе изучена за-
висимость реологических свойств растворов от концентрации пластификатора. Эксперименты прово- 
дились в широком диапазоне скоростей и частот сдвига при $25^{\circ} \mathrm{C}$. Исходный полимер характеризовали методом ИК-спектроскопии. Реологические эксперименты проводились с использованием техники ротационной реометрии. Было показано, что зависимость вязкости от скорости сдвига для всех исследованных образцов является ньютоновской, и такие трехкомпонентные системы являются вязкоупругими жидкостями. Можно предположить, что все исследуемые системы однородны при отсутствии следов воды. Конечной целью исследования был выбор оптимального состава (концентрации растворителя и пластификатора) и режима приготовления тонких пленок из этих систем, которые могли бы обеспечить получение твердого электролита для создания усовершенствованного электрического аккумулятора с гибкой полисульфоновай мембраной, выступающей в роли электролита и сепаратора. Данная работа посвящена исследованию реологических свойств, таких как вязкость и вязкоупругие свойства системы «полисульфон - растворитель - пропиленкарбонат» и зависимости их от состава и структуры растворов.

Ключевые слова: полисульфон, полимерные растворы, пластификатор, вязкость, вязкоупругие свойства, твердотельный электролит, тонкопленочная мембрана. 